\title{
Computational Fluid Dynamics (CFD) Simulation for Designing Mooring Bitts Position at the Barge for Wave Energy Conversion (WEC)
}

\author{
Irfan Syarif Arief ${ }^{1, *}$, I Ketut Aria Pria Utama ${ }^{2}$, Ridho Hantoro ${ }^{3}$, Juniarko Prananda ${ }^{1}$, \\ and Alfa Muhammad Megawan ${ }^{4}$ \\ ${ }^{1}$ Department of Marine Engineering, Institut Teknologi Sepuluh Nopember, Jl. Teknik Kimia, \\ Surabaya 60111, East Java, Indonesia \\ ${ }^{2}$ Department of Naval Architecture, Institut Teknologi Sepuluh November, Jl. Teknik Kimia, \\ Surabaya 60111, East Java, Indonesia \\ ${ }^{3}$ Department of Physics Engineering, Institut Teknologi Sepuluh Nopember, Jl. Teknik Kimia, \\ Surabaya 60111, East Java, Indonesia \\ ${ }^{4}$ Operation and Management of Maritime Systems, Hochschule Wismar, Philipp-Müller-Straße 14, \\ 23966 Wismar, Germany
}

\begin{abstract}
Potential wave energy in Indonesia between $5 \mathrm{~kW} \mathrm{~m}$ m $^{-1}$ to $20 \mathrm{~kW} \mathrm{~m}{ }^{-1}$ depending on-site location coastline. This research in ocean energy of Wave Energy Conversion (WEC) is wave activated body using the floating or motion hull due to kinetic and momentum energy from an ocean wave. The pendulum movement cause by a floating hull to drive the electric generator. The shape of the hull, displacement, and position point of the mooring line greatly influences the movement of the hull. This paper discusses how to computational fluid dynamics (CFD) simulation can solve and determine the best mooring line position in the hull. Moreover, the shape of the hull at under waterline or drought has slope angle $45^{\circ}$, length overall $3 \mathrm{~m}$, breadth $1.5 \mathrm{~m}$, depth $2 \mathrm{~m}$, and draft $0.65 \mathrm{~m}$. One of the boundary conditions in the domain CFD, the direction of a wave from inlet boundary to starboard or port side using regular wave. The position both of mooring bitts are at forwarding perpendicular and after perpendicular. Three-position of mooring bitts that have simulated CFD: (i) under the waterline, (ii) at the waterline, and (iii) up waterline. The result of simulation that the best position of mooring bitts is at the waterline.
\end{abstract}

Keywords: Floating, mooring computational fluid dynamics, motion hull, ocean energy, renewable energy

\section{Introduction}

Indonesia is an archipelago that has the most extended coastline number two in the world with a length, and every location has many kinds of type of characteristic ocean waves. Potential wave energy in Indonesia between $5 \mathrm{~kW} \mathrm{~m}^{-1}$ to $20 \mathrm{~kW} \mathrm{~m}^{-1}$ depending on-site location coastline. Many kinds of device Wave Energy Converters (WEC), in Figure 1, presented about three primary device there are Oscillation Water Column (OWC), Oscillation Bodies (OB) and Overtopping [1]. OWC are devices with a semi-submerged cylinder pipe or hollow, open both sides to the sea below. Seawater and air trapped pocket

*Corresponding author: irfansya@its.ac.id 
above a water column. The free surface between seawater and air produce waves forces the column moving up and down, forcing the air out of the chamber and back into it. The wave forces continuous movement a bidirectional stream of high-velocity air or potential energy seawater, which is a channel through a Power-Take-Off (PTO). The PTO system converts the airflow or water flow into energy using a turbine at above of column for airflow or at the bellow of the column for water flow [2].

The Oscillation Bodies (OB) types have barge structures that are likely to move by six degrees of freedom translation (surge, heave, sway) and rotation (roll, pitch, yaw) cause by energy-momentum from the impact of incident waves. When the activating barge structures meet wave force, then these motions are transformed into electric power depend on type device to capture wave energy. Among these types, OB types have the highest transfer efficiency because they directly exploit wave energy to generate power without any other steps, such as to make an airflow or to capture seawater, so the loss of wave energy is the least [3]. Overtopping devices have demonstrated some advantages over other WECs: unstable wave energy can be converted into relatively stable static energy of the water body, which can be used easily; low-head hydro turbine technology is well established in hydroelectric engineering. Consequently, overtopping performance has become a key factor in determining the reservoir capacity and power output duration [4]. Figure 2 presented about Wave Energy Converters (WEC) consist of Oscillating Water Column (OWC), Oscillating Bodies (OB), and Overtopping that developed new technologies by industry or team researcher from another country or institution. Full-sized OWC prototypes were built in Norway (in Toftestallen, near Bergen, 1985, [5]), Japan (Sakata, 1990, [6]), India (Vizhinjam, near Trivandrum, Kerala state, 1990, [7]), Portugal (Pico, Azores, 1999, [8]), UK (the LIMPET plant in Islay island, Scotland, 2000, [9]. The Oregon State University, USA had developed a linear electrical generator using a heaving buoy as like oscillating bodies system [10]. In Norway at Toftestallen, in the 1980s, developed a device overtopping and name of the device is The Tapchan (Tapered Chanel Wave Power Device), a prototype can produce rate power $350 \mathrm{~kW}$ [11].

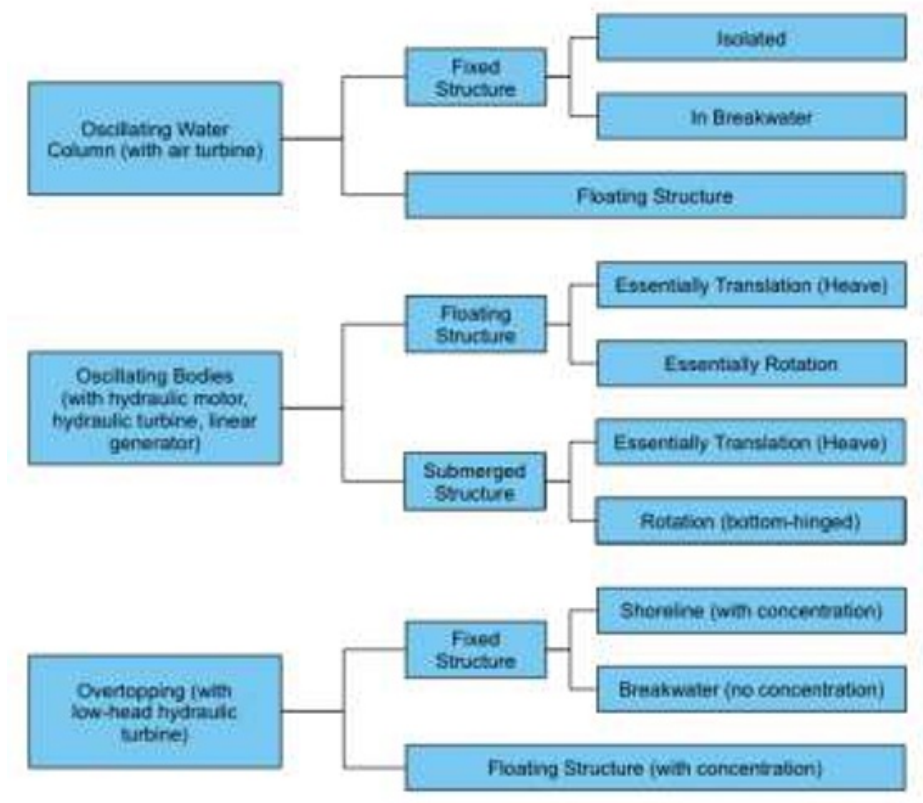

Fig. 1. Classification of wave energy device [1]. 


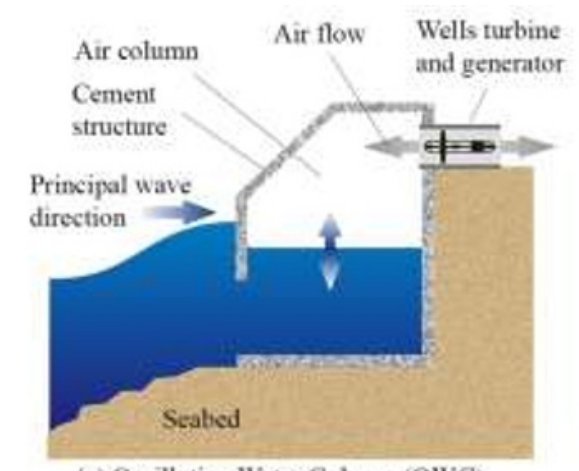

(a) Oscillating Water Column (OWC)

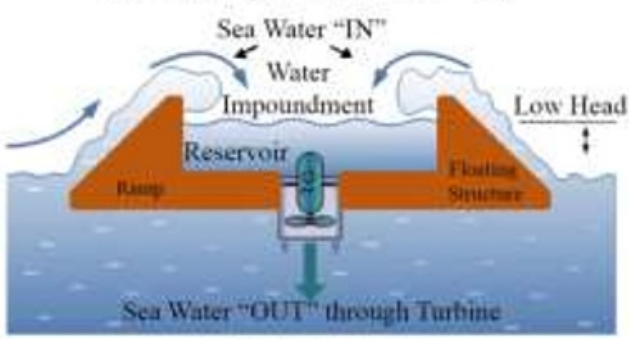

(b) Overtopping

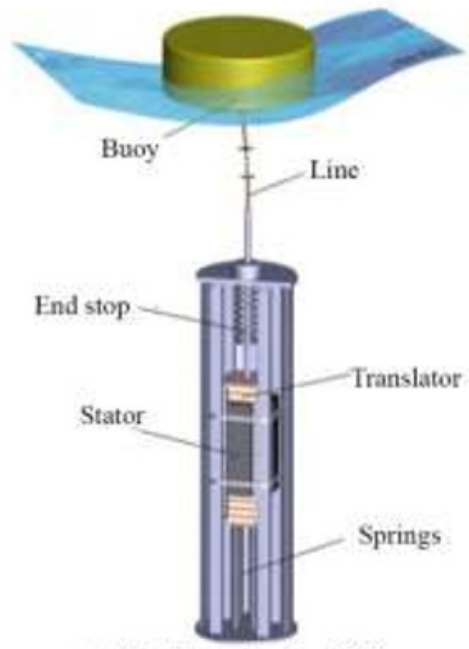

(c) Oscillating Bodies $(\mathrm{OB})$

Fig. 2. (a) Oscillating Water Column; (b) Overtopping, and (c) Oscillating Bodies (OB).

This research is using the motion of pendulum to drive an electric generator that type model is Oscillation Bodies and the pendulum device installed at the deck of barge structure. Description of source energy from to electric generator; a first step, an ocean wave energy directly to the barge and make motions translation and produce force through $\mathrm{x}$-axis, $\mathrm{y}$ - axis, and z-axis. Furthermore, make motions rotation and produce moment or torsion (Nm) Mxaxis, My-axis, and Mz- axis. A second step, force, and moment influence motions swing of the pendulum and using mechanisms gearbox to change actions, oscillate the pendulum to the full rotate one-direction. A third step, power output from gearbox, directly connects an electric generator to produce electric power. The shape of the barge dramatically influences the type of motions. Free-floating barge with an angle $45^{\circ}$ at portside and starboard hull could capture ocean wave energy to convert high-value moment or kinetic energy compared with other motions of models like a cylinder or box hull [12]. Barge movement that often occurs in free-floating is a roll, pitch, and heave [13]. This paper presented the position of mooring bitts influence motions of a barge. Three-position mooring bitts have simulated using the method of computational fluid dynamic (CFD) Fine Marine NUMECA. Fairlead position mooring bitts at (i) under the waterline, (ii) at the waterline, and (iii) up waterline. By using stiffness mooring $5000 \mathrm{~N} \mathrm{~m}^{-1}$ and initial tension zero $\mathrm{N}$ before to solve or iteration every case study.

\section{Methodology}

To solve the free-floating barge able to use the numerical method or experiment model laboratory scale. Before an experimental model able to simulate many case studies to reduce the cost of research, it is preferable. CFD simulation method has three-step to complete the simulation; geometry model (pre-processing), solve-processing, and post-processing. 


\subsection{Geometry model}

Domain for CFD simulation consists of the two-part object there are object body and object space of fluid. Figure 3 presented detail domain of simulation.

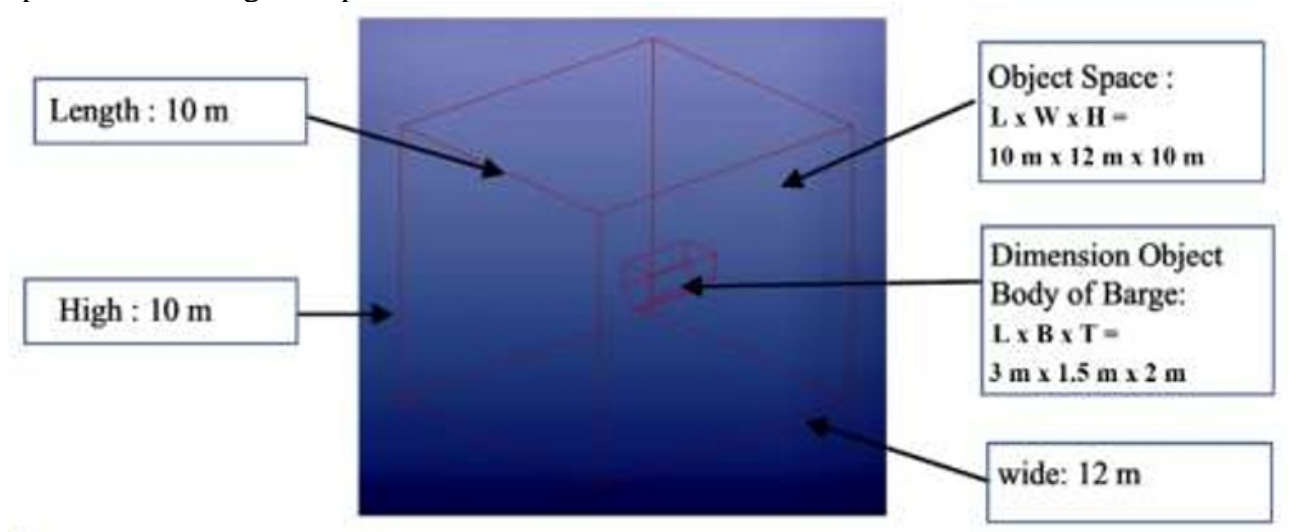

Fig. 3. Domain for CFD simulation.

\subsection{Meshing model}
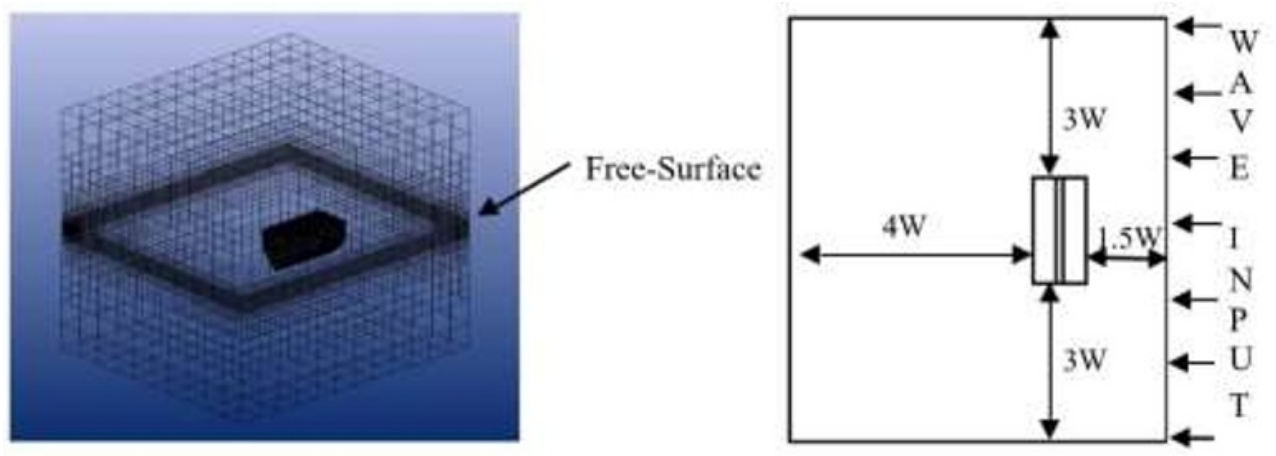

Fig. 4. Meshing model simulation and position barge in domain fluid.

Mesh quality significant before to input parameter CFD and solve-processing step. Negative cells and twisted cells have to be zero, orthogonality, and volume more than $80 \%$ is necessary. Figure 4 presented the meshing model and position body of the barge in domain fluid. Global mesh uses maximum number refinements of 5, and free-surface mesh uses maximum number refinements of 7 , which means more cell number and smaller cell size than a global mesh. The barge position ideal in the domain if 1.5 times wide dimension the barge from position wave input, and 2 to 3 times wide both sides and 4 to 5 times wide after the barge. Moreover, the total number of cells or grid is 539582 cells.

\subsection{Parameter input}

Parameter input for CFD simulation consists of steady or unsteady, fluid and flow model, boundary condition, body motion, and mooring coordinate. Table 1 below shows some of the parameters that are used. 
Table 1. Parameter input CFD simulation.

\begin{tabular}{|l|l|l|l|}
\hline Parameter & \multicolumn{1}{|c|}{ Value } & \multicolumn{1}{c|}{ Parameter } & \multicolumn{1}{c|}{ Value } \\
\hline General Paramete & Unsteady & Boundary Conditions: & \\
\hline Fluid Model & Multi-Fluid (air and water) & - Barge & Solid \\
\hline Flow Model: & & - Input Wave & Regular Wave \\
\hline - Turbulence Model & k-omega (SST-Menter) & Depth & $5 \mathrm{~m}$ \\
\hline - Froude Number & 0.19433 & Period & $6 \mathrm{~s}$ \\
\hline - Body Motion & All Solved & Height & $0.5 \mathrm{~m}$ \\
\hline
\end{tabular}

\subsection{Number of simulation and mooring parameter}

Table 2 below shows the number of the simulation to calculate the effect of mooring bitts at fairlead position at the barge.

Table 2. Parameter input CFD Simulation.

\begin{tabular}{|c|c|c|}
\hline No & Position Mooring Bitts & Code \\
\hline 1 & Free-Floating & A \\
\hline 2 & under the waterline & B \\
\hline 3 & at the waterline & C \\
\hline 4 & up waterline & D \\
\hline
\end{tabular}

Table 3. Coordinate of the mooring line.

\begin{tabular}{|c|l|c|c|c|c|c|c|}
\hline Code & & \multicolumn{3}{|c|}{ Fairlead Position $(\mathbf{x}, \mathbf{y}, \mathbf{z})$ meter } & \multicolumn{2}{c|}{ Anchor Position $(\mathbf{x}, \mathbf{y}, \mathbf{z})$ meter } \\
\hline \multirow{4}{*}{ B } & Line B1 & 0 & 1.5 & -0.4 & 2 & 5 & -5 \\
\cline { 2 - 8 } & Line B2 & 0 & 1.5 & -0.4 & -2 & 5 & -5 \\
\cline { 2 - 8 } & Line B3 & 0 & -1.5 & -0.4 & 2 & -5 & -5 \\
\cline { 2 - 8 } & Line B4 & 0 & -1.5 & -0.4 & -2 & -5 & -5 \\
\hline \multirow{4}{*}{ C } & Line C1 & 0 & 1.5 & 0 & 2 & 5 & -5 \\
\cline { 2 - 9 } & Line C2 & 0 & 1.5 & 0 & -2 & 5 & -5 \\
\cline { 2 - 8 } & Line C3 & 0 & -1.5 & 0 & 2 & -5 & -5 \\
\cline { 2 - 8 } & Line C4 & 0 & -1.5 & 0 & -2 & -5 & -5 \\
\hline \multirow{4}{*}{ D } & Line D1 & 0 & 1.5 & 0.5 & 2 & 5 & -5 \\
\cline { 2 - 8 } & Line D2 & 0 & 1.5 & 0.5 & -2 & 5 & -5 \\
\cline { 2 - 8 } & Line D3 & 0 & -1.5 & 0.5 & 2 & -5 & -5 \\
\cline { 2 - 8 } & Line D4 & 0 & -1.5 & 0.5 & -2 & -5 & -5 \\
\hline
\end{tabular}

Table 2 above shows the fairlead position of the mooring line at the barge and position mooring line at the bottom of the sea or anchor position mooring line. In Table 3, code A does not show the cause of the free-floating condition or no mooring connect. All mooring line initial tension is zero $\mathrm{N}$ and stiffness line mooring $5000 \mathrm{~N} \mathrm{~m}^{-1}$. 


\subsection{Computation control}

Parameter setting at solver-processing in this case study use number of time steps 1500 , time step law uniform, and time step value is $0.05 \mathrm{~s}$. Furthermore, the output parameter shows in Table 4 for the analysis motion of the barge.

Table 4. Parameter output.

\begin{tabular}{|c|c|}
\hline Parameter & Output \\
\hline Translation Variable & $\mathrm{Tx}, \mathrm{Ty}, \mathrm{Tz}$ \\
\hline Velocity Variable & $\mathrm{Vx}, \mathrm{Vy}, \mathrm{Vz}$ \\
\hline Rotational Variable & $\mathrm{Rx}, \mathrm{Ry}, \mathrm{Rz}$ \\
\hline Angular Velocity Variable & $\mathrm{dRx}, \mathrm{dRy}, \mathrm{dRz}$ \\
\hline Force Variable & $\mathrm{Fx}, \mathrm{Fy}, \mathrm{Fy}$ \\
\hline Moments & $\mathrm{Mx}, \mathrm{My}, \mathrm{Mz}$ \\
\hline
\end{tabular}

\section{Analysis}

Post-processing is the last step to get a result of CFD simulation to know visual or numeric data. The figure below presented the comparison of pitch motions (Ry) with different positions of mooring bitts shown in Table 2 and the $\mathrm{x}$-axis of times. The roll $(\mathrm{Rx})$ and yaw (Rz) no significant difference.

Condition the A is free-floating, and values of Ry in degree is higher than all condition cause off not mooring connected at the barge. Position mooring $\mathrm{C}$ or mooring bitts at the waterline is the best than $\mathrm{B}$, and $\mathrm{D}$. Figure 6 presented the comparison of moment My at $\mathrm{y}-$ axis. Mx and Mz no significant difference. The moment $\mathrm{y}$-axis (My) has a fluctuated value, and the maximum moment condition $\mathrm{C}$ ranges between $1250 \mathrm{Nm}$ to $2500 \mathrm{Nm}$ corresponds to the application of the WEC pendulum system, which requires the greatest moment.

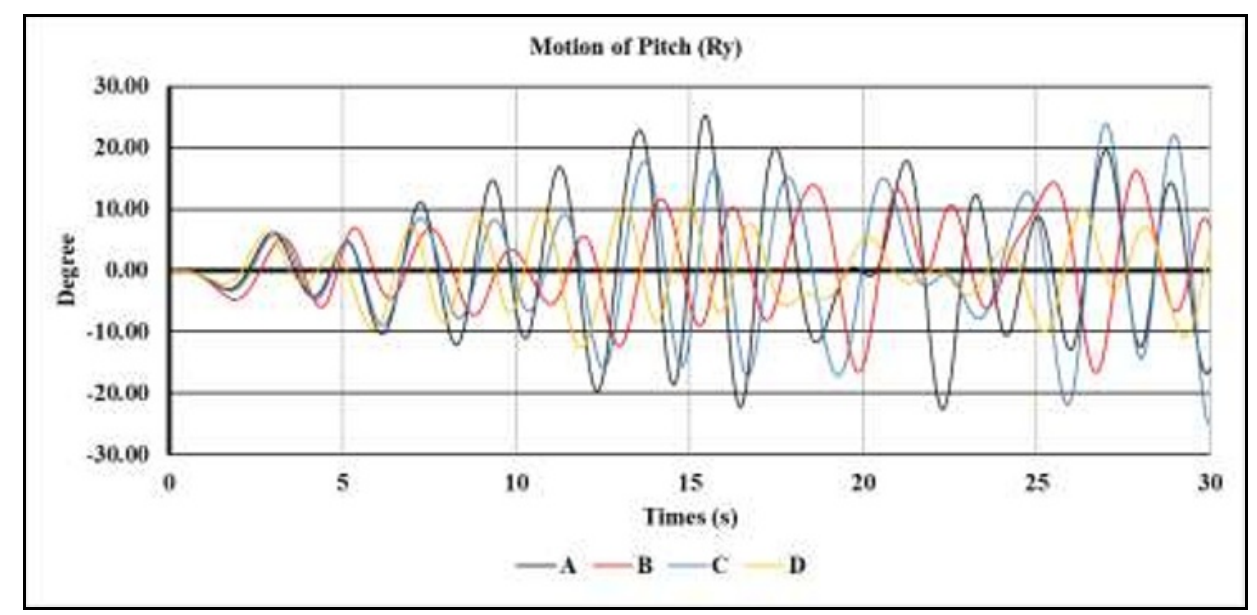

Fig. 5. Comparison of pitch motions (Ry). 


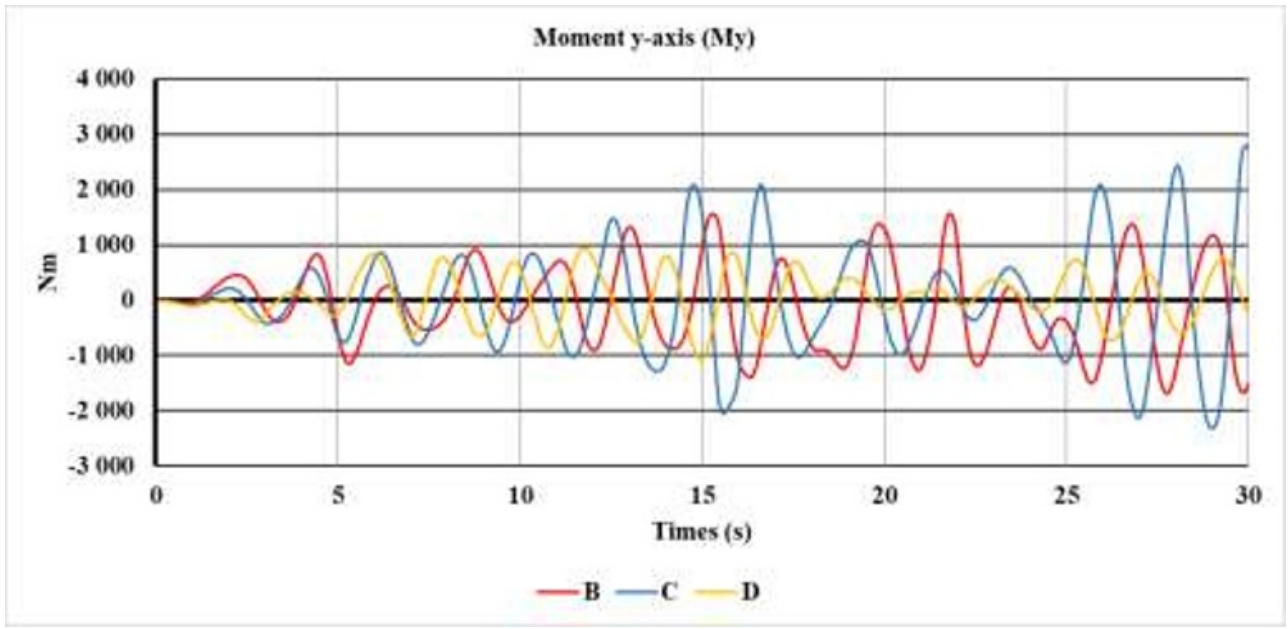

Fig. 6. Comparison of the moment (My).
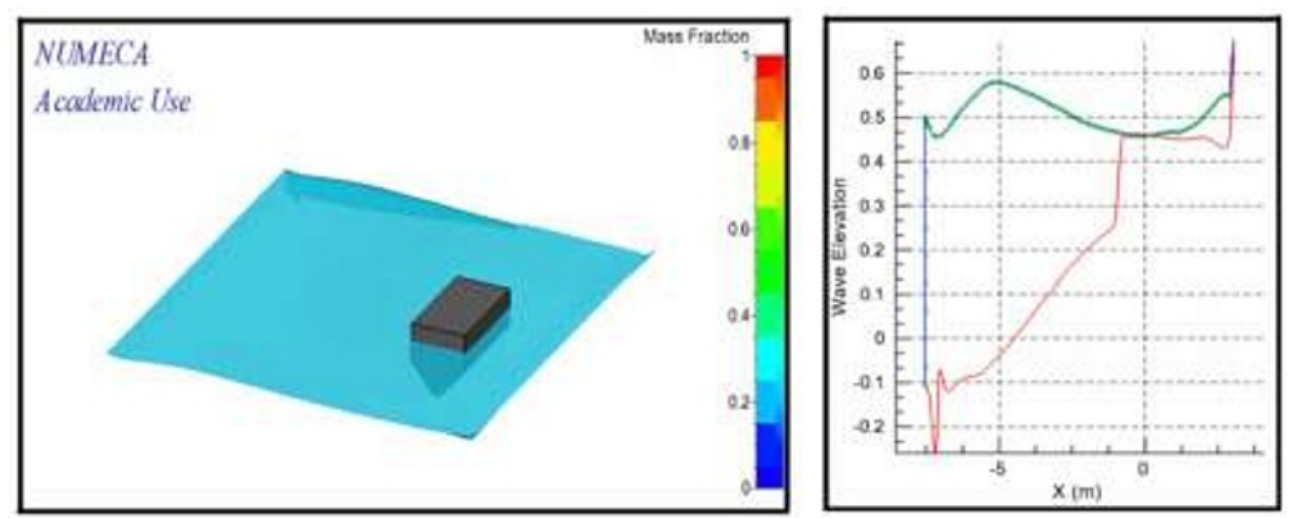

Fig. 7. Mass fraction free-surface and wave elevation.

Figure 7 presented mass fraction that means is the boundary of the free-surface between air and water. Wave elevation that means is graphic elevation tell about position height wave at this time step.

\section{Conclusion}

This paper shows how CFD simulation can be able to solve simple case study to know where location or fairlead position of mooring bitts. Fairlead or mooring bitts position at the waterline or condition $\mathrm{C}$ is the best more than another case study in the CFD simulation. Our research is to develop a WEC pendulum (OB) system mounted on a deck barge, which requires the greatest pitch or roll barge motion and moments to swing the best pendulum as the prime mover. For further research, suggestions are to conduct simulations with various input characteristics of regular and irregular waves, anchor position at the bottom, and mooring line stiffness. For validation of CFD simulation is necessary to do experiments model before carrying out the implementation. 


\section{References}

1. A.F. de O. Falcao, Renew. Sust. Energ. Rev., 14,3:899-918(2010)

https://www.sciencedirect.com/science/article/pii/S1364032109002652

2. T.V. Heath, Phil. Trans. R. Soc. A, 370:235-245(2012).

https://royalsocietypublishing.org/doi/pdf/10.1098/rsta.2011.0164

3. S.-S. Kim, J.-C. Lee, D. Kang, S.-S. Lee, Int. J. Nav. 11,1:244-255(2019). https://www.sciencedirect.com/science/article/pii/S2092678218300244?via\%3Dihub

4. Z. Liu, H. Shi, Y. Cui, K. Kim, Renew. Energ., 104:163-176(2017). https://www.sciencedirect.com/science/article/abs/pii/S0960148116310965?via\%3Dih $\underline{\mathrm{ub}}$

5. C. Mei, Hydrodynamics of two devices for wave-power extraction. Proceedings of the $5^{\text {th }}$ International Conference on Asian and Pacific Coasts (Singapore, 2009). 1: 3-18(2009). https://www.worldscientific.com/doi/abs/10.1142/9789814287951_0001

6. V. Sundar, T. Moan, J.H. Todalshaug, Conceptual design of OWC wave energy converters combined with breakwater structures. Paper Presented in The 29th International Conference on Ocean, Offshore and Arctic Engineering (Shanghai, China, 2010).

https://www.researchgate.net/publication/287843022_Conceptual_Design_of_OWC

Wave Energy_Converters_Combined_With_Breakwater_Structures

7. S. Neelamani, V. Reddy. International Journal of Earth Sciences and Engineering, 3,6:1-12(2010).

https://www.researchgate.net/publication/286742795_Ocean_energy_technology_deve lopment_-_The_challenge_of_this_millennium

8. K. Monk, V. Winands, M. Lopes, Renew. Energ. 128,Part A:230-240(2018) https://www.sciencedirect.com/science/article/abs/pii/S0960148118304452

9. M. Mueller, R. Wallace. Energy Police, 36,12:4376-4382(2008). https://www.sciencedirect.com/science/article/abs/pii/S0301421508004539

10. D. Elwood, A. Schacher, K. Rhinefrank, J. Prudell, S. Yim, E. Amon, et al. Numerical modelling and ocean testing of a direct-drive wave energy device utilizing a permanent magnet linear generator for power take-off. Paper Presented in 28th International Conference on Ocean Offshore Arctic Engineering (Hawaii, 2009). OMAE200979146:817-824(2009). https://asmedigitalcollection.asme.org/OMAE/proceedingsabstract/OMAE2009/43444/817/337086

11. E. Mendoza, X. Chávez, J.C. Alcérreca-Huerta, R. Silva, Ocean Engineering 106:252260(2015). https://www.sciencedirect.com/science/article/abs/pii/S0029801815002796

12. I.S. Arief, Zamrisyaf. (2010). Analysis of barge models to capture the energy from ocean wave. Paper Presented in ICSOT-International Conference on Ship and Offshore Technology (Surabaya, Indonesia, 2010).

https://www.academia.edu/6417240/Paper_ICSOT-Irfan_Syarif-ITS

13. I.S. Arief, I.K.A.P. Utama, R. Hantoro, J. Prananda, T.R. Arvisa, R.F. Kusuma. Mooring experimental study of motion response for pendulum wave energy converters. The 1st International Conference on Advanced Engineering and Technology, Surabaya, Indonesia, 2018). IOP Conference Series: Materials Science and Engineering, 462: 1-6(2019). https://iopscience.iop.org/article/10.1088/1757-899X/462/1/012010/pdf 